\title{
GENUS SOREX.-LINN.
}

DENTAL FORMULA.

Incisive $\frac{2}{2} ;$ Lateral incisive or false Canine from $\frac{3 \text { to } 5}{2-2} ;$ Molar from $\frac{4 \text { to } 5}{3-3}$; from 26 to 34 teeth.

Incisive teeth in the upper jaw indented at their base; in the lower, proceeding horizontally from their aveoli and turned upwards towards their points where they are usually of a brown colour; lateral incisive or false canine, conical, small, shorter than the cheek-teeth.

Muzzle and nose, much elongated; snout, moveable. Ears and eyes, small; pendactylous; nails, hooked. A series of glands along the flanks, exuding a scented unctuous matter.

The generic name is derived from the Latin word Sorex, a Shrew, field rat.

Authors have described about twenty-three species of Shrews, twenty existing on the Eastern continent and thirteen in N. America. Many of these species are not as yet determined, we can scarcely doubt from past discoveries that this number will in time be greatly increased. They are, no doubt, susceptible of being arranged into different groups and genera.

We know no genus in which the American naturalist has a greater prospect of success in adding new species than that of Sorex.

\section{SOREX PARVUS.-SAY.}

\section{Say's Least Shrew.}

PLATE LXX.

S. supra fuscenti-cinereus, infra cinereus ; dentibus nigricantibus ; cauda brevi, sub-cylindrica.

voL. II. -19 . 


\section{$2 \mathrm{BHL}$ Biodiversity Heritage Library}

Audubon, John James and Bachman, John. 1851. "Genus Sorex." The quadrupeds of North America 2, 145-145. https://doi.org/10.5962/p.322450.

View This Item Online: https://www.biodiversitylibrary.org/item/108514

DOI: https://doi.org/10.5962/p.322450

Permalink: https://www.biodiversitylibrary.org/partpdf/322450

\section{Holding Institution}

Duke University Libraries (archive.org)

\section{Sponsored by}

Duke University Libraries

\section{Copyright \& Reuse}

Copyright Status: Not provided. Contact Holding Institution to verify copyright status.

This document was created from content at the Biodiversity Heritage Library, the world's largest open access digital library for biodiversity literature and archives. Visit BHL at https://www.biodiversitylibrary.org. 